\title{
Taming Leviathan: Mitigating Political Interference in Sovereign Wealth Funds' Public Equity Investments
}

\author{
Bernardo Bortolotti \\ Università di Torino \\ Sovereign Investment Lab, BAFFI-Carefin Center \\ Università Bocconi \\ Veljko Fotak \\ University at Buffalo \\ Sovereign Investment Lab, BAFFI-Carefin Center \\ Università Bocconi \\ Giacomo Loss \\ Sovereign Investment Lab, BAFFI-Carefin Center \\ Università Bocconi
}

Extant research finds that targets of sovereign wealth fund (SWF) investments experience a weaker stock price reaction at investment announcement than targets of private-sector investments. We find that SWFs from autarchic countries can mitigate this "SWF discount" by signaling a passive stance, namely by investing through subsidiaries, buying small stakes, and not acquiring control. Conversely, SWFs from democratic countries reduce the discounts when signaling an active stance. The long-term operating performance of democratic (autarchic) SWF investment targets is also positively affected by an active (passive) stance. Nonetheless, funds from autarchic countries resort to passivity less often.

Keywords: Sovereign Wealth Funds, Political Risk, Corporate Governance.

\section{INTRODUCTION}

Sovereign wealth funds (SWFs) are a large and growing class of investors. Estimates of their exact size vary, but, at approximately USD 8 trillion in aggregate assets under management, they dwarf other classes of asset managers such as hedge funds (USD 3.2 trillion) or private equity funds (USD 2.49 trillion). Even more, SWFs are the fastest growing class of institutional investors over the past decade. ${ }^{1}$ Due to their sheer size, it is important to understand how they affect the valuation of the firms in which they invest. As institutional shareholders with substantial capital, no explicit liabilities, and long (multigenerational) investment horizons, SWFs have the potential to be the value-enhancing blockholders described by extant research on institutional shareholders (Shleifer and Vishny, 1986). Yet, anecdotal 
evidence and extant research suggest that SWFs are often under pressure to pursue multiple, often conflicting, objectives (Bortolotti, Fotak, and Megginson, 2015). Accordingly, SWFs might act as channels of political interference, imposing goals on target firms that are, at times, in conflict with shareholder value maximization (Shleifer and Vishny, 1994; Megginson and Netter, 2001; Estrin et al., 2009). The academic literature offers generalized results, yet SWFs originate from very heterogeneous countries, with very different political system. Accordingly, we question whether the impact of SWFs on target valuation depends on the political and institutional endowment of the country in which they are based. Particularly, we hypothesize that, as politicians in autarchic countries face fewer checks and balances on their behavior (weaker legal institutions, less freedom of the press, lower political competition, fewer veto players), SWFs originating from those countries might be more likely to impose political goals, rather than shareholder value maximization. Further, we investigate whether SWFs, and especially SWFs based in non-democratic countries, can mitigate a potentially negative impact on target valuation by signaling a passive stance insulating investment targets from political interference.

Bortolotti, Fotak, and Megginson (2015-from here on, "BFM") document a "sovereign wealth fund (SWF) discount": the announcement-period abnormal returns of sovereign wealth fund (SWF) equity investments in publicly traded firms are positive, but lower than those of comparable private investments. Their evidence supports the hypothesis that political interference negatively affects both firm value and performance, suggesting that the discount is due to markets pricing the threat of politicians imposing a non-commercial agenda in their investment targets. Announcements of SWF investments are associated with a positive mean abnormal return of $0.38 \%$, compared with the $4.45 \%$ mean abnormal return generated by the benchmark sample of private investors. Even after matching countries and timeframes, BFM noted that SWF acquisitions differ from those by private financial investors: SWFs tend to target larger and more profitable firms, but they also tend to buy smaller stakes and acquire controlling shares less frequently. Yet, even after controlling for these target and deal differences, the estimated "SWF discount" is statistically and economically significant, with a mean of $-1.31 \%$. Conservative estimation translates that into an average discount on firm market capitalization of $\$ 60$ million for each SWF investment, or an aggregate discount of $\$ 54$ billion in the sample we study. Given the magnitude of the impact on firm value, it is important to understand whether all SWFs suffer from similar discounts and whether effective mitigating mechanisms exist.

Starting from the results of BFM and using a manually constructed dataset of 900 investments by SWFs (or by SWF-owned investment subsidiaries) in publicly traded firms, over the 1980-2012 period, and a "benchmark" control sample of 5,350 stock purchases by private financial investors, we find that the discount, while associated with SWFs originating from both democratic and autarchic countries, is larger for the latter group. While SWFs based in democratic countries (for simplicity, we will call them "democratic SWFs") experience a discount of $-1.12 \%$, SWFs from autarchic countries ("autarchic SWFs") experience a discount of $-1.57 \%$. In robustness tests, we classify countries on the basis of the strength of constraints on the governing executive and find consistent results, indicating that the SWF discount is larger in countries with weaker institutional constraints.

Having established the existence of a SWF discount and the link with the strength of democratic institutions in the host country, we hypothesize that SWFs - and, in particular, autarchic SWFs - might be able to mitigate such a discount by insulating fund managers from political interference and by signaling a passive stance. We posit that SWFs might do so in various ways. First, a SWF might adopt a governance structure that insulates managers from political pressures - or, at least, one that enhances independent decision making. To test this hypothesis, we build a variable measuring the proportion of private-sector (non-political) directors on the SWF board, as an inverse proxy for the extent of involvement of politicians in the management of the fund. In robustness tests, we use an index of political interference based on SWF governance score by Truman (2008 and 2011) as an alternative metric of SWF political independence. Second, SWFs might refrain from purchasing large stakes and, especially, might refrain from obtaining control over the investment target. Third, SWFs might not elect representatives to the target's board of directors, even though the stake acquired might be large enough to justify representation. Fourth, SWFs might co-invest with private-sector partners, to signal a commitment to shareholder value 
maximization. Fifth, SWFs might invest indirectly, via subsidiaries or affiliated companies that are either fully or partially owned by the SWF itself. Sixth, SWFs might invest abroad, as both the incentives and the ability of politicians to affect investment targets are lower for foreign investments.

In a regression framework, we investigate whether the size of the discount differs depending on the type of country of origin of the investing SWF (democratic vs. autarchic) in interaction with these "discount-mitigating" mechanisms. We find, for all funds, a positive association between foreign investments and the market reaction, suggesting that investors are more concerned about political interference in domestic deals. For SWFs originating from democratic countries, we find a statistically and economically significant positive association between the market reaction (compared to private-sector acquirers) and the binary variables identifying large and controlling stakes and direct investments. This suggests that markets react favorably to signals of an active stance by democratic SWFs. For SWFs originating from autarchic countries we find, instead, a negative association with controlling stakes and direct investments, suggesting that markets value a passive stance by autarchic SWFs.

We further investigate the impact of SWFs on the operating performance of target firms. As BFM documented, SWF targets suffer from deteriorating profitability (return on assets) and valuation (marketto-book ratio) over the three years following the investment, compared to targets of private-sector investments. Our novel analysis, in a regression framework, confirms patterns mirroring the short-term market reaction: autarchic SWFs are associated with an increase in ROA when they signal passivity (by purchasing small, indirect stakes), while the opposite is true for democratic SWFs. We further find that firm valuation (measured by market-to-book ratios) increases when democratic SWFs appoint directors to the board of investee firms, while the opposite is true for autarchic SWFs.

Finally, having shown that a passive stance is associated with higher valuation and stronger operating performance for autarchic SWFs, while the opposite is true for democratic SWFs, we question whether SWFs act in a manner consistent with the maximization of target firm valuation. That is, we test whether autarchic SWFs are more likely than democratic SWFs to signal passivity to mitigate the adverse market reaction. BFM noted that, compared to the benchmark private-sector deals, SWF investments are more likely to be cross-border, involve smaller stakes, and are less likely to involve controlling stakes, suggesting that, overall, SWFs do try to invest with a "hands-off" approach. Yet, when we compare autarchic SWFs to democratic SWFs, we find surprising results. Autarchic SWFs are less likely to be insulated from government interference with a large portion of independent directors and are more likely to invest directly (rather than via subsidiaries) and more likely to invest domestically. We also find some evidence that those funds are more likely to appoint directors and assume control. Finally, we find that autarchic SWFs are more likely to invest in regulated industries, but the result is not statistically significant. Overall, these findings reveal that, despite the negative market reaction, funds from autarchic countries are more likely to take an active stance in their investments. Given the evidence of significant costs of such a stance (in terms of deteriorating investment value), our evidence strongly suggests that SWFs from autarchic countries could greatly benefit from the adoption of political risk mitigating strategies.

Our research adds to the literature on SWFs. The closest paper, in this sense, are Knill, Lee, and Mauck (2012b), in which the authors documents that SWFs do not positively impact firm value as other institutional investors, and BFM, as the authors document that the market reaction to SWF investments is weaker than the reaction to private-sector investments. We extend this line of inquiry with a focus on the "SWF discount" and a novel analysis of mitigating mechanisms. ${ }^{2}$ While BFM focus on the determinants of the market reaction, we focus on the drivers of the discount (the difference between the market reaction to SWFs vs private-sector investments) by, first, presenting evidence that the market reaction to SWF investments is conditioned on the level of democracy of the SWF hosting country. Second, we find that SWFs have means to mitigate this discount, but the optimal strategy depends on the level of democracy of the host country. For SWFs hosted in democratic countries, it is optimal to signal an active stance, while the opposite is true for SWFs hosted in autarchic countries.

Our investigation further contributes to explaining inconsistent findings in extant literature. When investigating the long-term impact of SWF investments on firm value, BFM find evidence of 
deteriorating profitability and lower valuation, while Kotter and Lel (2011) find consistent evidence but note weak statistical significance. In contrast, Dewenter, Han, and Malatesta (2010) document a valueenhancing effect of SWF ownership due to the provision of enhanced monitoring as active investors. We show that funds from democratic countries have the potential to add value with an active stance (consistent with Dewenter, Han, and Malatesta, 2010), while funds from autarchic countries can mitigate the "SWF discount" by signaling a passive, hands-off approach (consistent with Bortolotti, Fotak, and Megginson, 2015, and Kotter and Lel, 2011).

Our research contributes also to the broader corporate finance literature, by focusing on how "undesirable shareholders" can mitigate the adverse impact on firm valuation that their investments might elicit. While extant literature has focused on value-enhancing institutional shareholders, by documenting that not all institutional ownership is value increasing and that not all institutional investors are good monitors (Chen, Harford, and Li, 2007; Brav et al., 2008; Klein and Zur, 2009; Ferreira and Matos, 2008), it has largely ignored shareholders whose identity has a negative impact on firm value. While our investigation is specific to SWFs, there is abundant anecdotal evidence of adverse reactions to investments by other state-owned entities, or even by private entities based in non-democratic countries. Our evidence carries implications for all "undesirable shareholders," by showing how signaling a passive stance can mitigate adverse market reactions.

The remainder of the manuscript is structured as follows. We develop testable hypotheses in Section 2. We discuss data sources, data collection methodologies, and offer descriptive statistics in Section 3. We discuss our empirical methodology and results in Section 4. We conclude in Section 5.

\section{HYPOTHESES AND TESTABLE PREDICTIONS}

\section{Democracy and the SWF Discount}

Sovereign wealth funds (SWFs) have the capability and incentives to monitor portfolio firm managers and increase firm value by engaging actively in the governance of target companies. While other institutional investors at times play a similar monitoring role (Ferreira and Matos, 2008), the lack of explicit liabilities, the long-term investment horizon, the low need for short-term liquidity, and the capability to acquire large stakes differentiate SWFs from private financial investors, which could be reflected in higher relative valuations of investment targets. In this sense, SWFs could be the monitoring and value-increasing institutional shareholders envisioned by Shleifer and Vishny (1986). In addition, SWFs could offer valuable connections to target firms, either in terms of market access, access to government contracts, or access to financing by state-owned banks. Finally, Bertoni and Lugo (2014) find that SWF investments provide an implicit guarantee on the debt of target firms, by signaling support for distressed firms. We call this the "Valuable blockholder" hypothesis.

On the other hand, since sponsoring governments may impose noncommercial, political objectives, not fully consistent with the shareholder wealth maximization typically pursued by private firms, target valuation might be negatively affected (Shleifer and Vishny 1994; Megginson and Netter 2001; Estrin et al. 2009). These objectives can be in the best interests of politicians (tunneling of resources for private benefits), of their constituencies (in an attempt to gain votes and support, as in Grogoryan, 2016), or social: for example, developing certain sectors of the economy, acquiring access to technology or natural resources (Knill, Lee, and Mauck, 2012a), further foreign policy and geopolitical agendas (Helleiner, 2009; Cohen, 2009; Drezner, 2009; Kaminski, 2017), or maximizing employment. In either case, conflicting goals have the potential to negatively affect firm value. Consistent with the above, Chhaochharia and Laeven (2009) and Knill et al. (2012a) show that SWF investments are influenced by political (rather than economic) factors. These findings are echoed by many single-country or regional case studies; for example, Norris (2016) and Kaminsky (2017) find that Chinese SWFs are tools of "economic statecraft" aimed at insuring, among other things, access to natural resources. We call this the "political interference" hypothesis.

The SWF discount documented by BFM is consistent with existing theory and empirical evidence suggesting that politicians are "bad owners" of corporations - and, within the above framework, with the 
political interference hypothesis. ${ }^{3}$ Yet, we question whether this discount is specific to some funds, or stronger for certain funds - namely, funds from autarchic countries. SWFs are supposed to be insulated from direct influence from politicians - and virtually all carry provisions restricting the ability of politicians to divert funds. We posit that such restrictions are more effective in democratic countries than in autarchic ones. ${ }^{4}$ Further, the strength of democratic institutions appears to directly impact the quality of SWF governance and its transparency: Wang and Li (2016) argue that "SWFs, which reside in nondemocratic countries and operate in political environments with too few or too many veto players, are most likely to have weak governance rules and remain opaque. In such cases, the SWFs are likely to deviate from private investors and serve home countries' political agendas." Accordingly, we test whether the political interference hypothesis and the consequent drop in firm valuation are specific to funds originating from autarchic countries and countries with weak constraints on the executive.

\section{Mitigating the Discount}

Given the extant evidence of a SWF discount, we question whether funds can mitigate this negative impact on firm valuation, either by developing an internal governance structure that insulates the fund itself from political interference, or by signaling a passive stance in the management of its investment targets. Wang and Li (2016) argue that well-defined governance rules "assuage concerns that they serve home countries' political agendas and extract undue benefits from close ties with home governments." We note that there is much concern amongst media, regulators, and managers about the investment purpose of SWFs, which is often compounded by low levels of transparency of the funds (Truman, 2008; Mattoo and Subramanian, 2008). According to Kotter and Lel (2011), "SWF objectives and behavior are not well understood. In particular, the foreign government ownership of these investment funds coupled with the opaqueness surrounding their structure and activities are among the major concerns in host countries including the United States." We posit that SWFs could signal an intention to be passive shareholders and hence reduce the opacity surrounding their true motives and mitigate the discount documented in extant literature. We hypothesize that such signals of passivity would be most valuable for SWFs based in autarchic regimes, as the ex-ante risk of interference is greater for such funds.

\section{SWF Governance and Independent Private-Sector Directors}

Grogoryan (2016) discusses how politicians and ruling elites control the behavior of SWFs via director appointments. Conversely, one way for a fund to insulate itself from political interference is to have a large portion of independent (non-politically affiliated) directors. In addition, extant literature finds that independent directors monitor managers and prevent value-destroying bids (Byrd and Hickman, 1992). Accordingly, the appointment of private-sector directors could serve as a signal to market participants, indicating that politicians are not going to intervene with the management of the fund, or of its investment holdings.

\section{Size of the Stake and Control}

The degree of influence a shareholder fund has on an investment target is related to the voting rights it obtains in the target. Accordingly, a SWF could signal a passive approach by simply purchasing stakes with small voting rights, or by avoiding controlling stakes. In addition, in many jurisdictions around the world, small stakes might avoid reporting requirements, thus decreasing media and regulatory attention to the deal, and further mitigating adverse reactions.

\section{Director Appointments}

One of the ways in which large blockhoders affect firm behavior is by appointing directors to the board of the investment target (for example, Klein and Zur, 2009 discuss how hedge funds and other activists successfully influence firms in which they acquire stakes by gaining board representation). Accordingly, a SWF could signal a passive approach by not appointing directors. 


\section{Co-investments}

SWFs might signal a passive approach, or, at least, a non-politicized approach, by co-investing with private parties, whose goal is presumably the maximization of investment value. The presence of privatesector co-investors could further certify the shareholder-value orientation of the investing syndicate.

\section{Direct Investments}

Another way for SWFs to signal a passive approach is by investing via subsidiaries (fully or partially) owned by the investing SWF. Murtinu and Scalera (2016) consistently find that opaque and politicized funds are more likely to invest via investment vehicles, presumably to signal a passive investment approach-yet, they offer no evidence of the impact of such strategy, which is our main focus. Presumably, the additional distance between the politicians and the investment target could further insulate the target from political interference.

\section{Foreign Investments}

Political interference is less likely when the target is foreign, for multiple reasons. First, the incentives to interfere are lower, as politicians are less concerned about, for example, foreign employment levels than domestic ones. Second, the ability to influence a foreign company is lower, as politicians do not have regulatory powers abroad, and certainly weaker channels of indirect influence (such as the threat of selective enforcement or punitive taxation). Finally, foreign deals generally receive more oversight, as they tend to trigger strong attention by the media and, often, additional regulatory oversight, which reduces the threat of tunneling. For all the above reasons, SWFs might mitigate their negative impact on firm valuation by investing abroad.

\section{Regulated Industries}

García-Canal and Guillén (2008) note that "While regulation has come to affect virtually every sector of the economy, the so-called 'regulated' industries (e.g. telecommunications, electricity, water, oil, gas, and banking) are subject to an unusual degree of intervention and policy risk. In these industries, governments have the ability to dramatically alter the profitability of firms and investment projects." Given the stronger impact of government intervention in regulated industries and the higher risk of political distortions, SWFs might mitigate the threat of political interference by refraining from investing in regulated industries.

\section{DATA AND DESCRIPTIVE ANALYSIS}

In this section, we describe variables and data sources. A list of all variables, variable definitions, and data sources are presented in in the appendix in Table A1.

\section{Sovereign Wealth Fund Definition and List}

Despite a growing SWF literature, there still is no consensus on exactly what constitutes a "sovereign wealth fund." This study employs the Sovereign Investment Lab's (SIL) selection criteria, presented in Miracky and Bortolotti (2009) and employed by Bortolotti, Fotak, and Megginson (2015), which defines a SWF as (1) an investment fund rather than an operating company, (2) being wholly owned by a sovereign government, but organized separately from the central bank or finance ministry to protect it from excessive political influence, (3) making international and domestic investments in a variety of risky assets, (4) being charged with seeking a commercial return, and (5) a wealth fund rather than a pension fund, meaning that the fund is not financed with contributions from pensioners and does not have a stream of liabilities committed to individual citizens. ${ }^{5}$ These criteria yield a sample of thirty-three sovereign wealth funds from twenty-one countries. We find sufficient data for empirical analysis on public equity investments for nineteen of those funds, based in fourteen countries distinct countries. The full list of funds used in empirical analysis is available in the appendix. 


\section{The Sovereign Wealth Fund Investment Sample}

The sample of SWF investments analyzed here originates from the SIL SWF Database. We follow, as closely as feasible, the sample construction methodology used by Bortolotti, Fotak, and Megginson (2015). The data include investments in listed and unlisted equity, commercial real estate, private equity funds, and joint ventures in which a SWF (or one of its majority-owned subsidiaries) is an investor. ${ }^{6}$ The data are assembled using information from five databases (Thomson One Banker, Bloomberg, the Thomson Reuters SDC Mergers and Acquisitions database, the Zephyr Mergers and Acquisitions database, and Zawya) integrated with data from fund Web sites and from various news sources. ${ }^{7}$ We rely on $13 \mathrm{~F}$ filings to track investments by Norway's SWF. ${ }^{8}$ From this dataset, we select a subset of investments by SWFs (or their majority-owned subsidiaries) in publicly traded firms, as we require firmlevel data. We further restrict our analysis to deals announced between January 1980 (the start point of the SIL database) and December 2012 (to allow for three-years of post-acquisition data, so we can investigate the impact of SWF investments on firms' operating performance). Our final sample contains 900 investments by SWFs (or majority-owned subsidiaries) in publicly traded targets, for a total value of \$254 billion (in USD adjusted to the year 2000). ${ }^{9}$

\section{Measuring the Strength of Democratic Institutions}

To measure the strength of democratic institutions, we use data from the Polity IV Project database. In particular, for each country-year, we compute the average difference between the "Autocracy" and "Democracy" scores. A similar metric has been widely used in extant literature, as in Ayyagari, Demirgüç-Kunt, and Maksimovic (2006) and Rodrik and Wacziarg (2005).

We identify funds based in democratic (autarchic) countries; for brevity, we refer to those as "democratic funds" ("autarchic funds"). The funds with the highest democracy indices are those from Australia and Norway, scoring a perfect ten on the Polity index. Other funds with positive scores include South Korea's Korean Investment Corporation (with an index of 8) and Malaysia's Khazanah Nasional Berhard (6). We identify these four funds as being based in "democratic" regimes and the rest as "autarchic" - for brevity, we refer to SWFs based in democratic countries as "democratic SWFs" and to the rest as "autarchic SWFs." In robustness tests, we (1) re-classify Malaysia's fund as autarchic and (2) replicate all analysis excluding investments from Malaysia, but our main findings are unaffected.

Collectively, the group of democratic funds accounts for approximately half of all deals (by count), but Norway's fund heavily dominates the group of democratic funds (Norway accounts for about $90 \%$ of democratic deals by count and about $50 \%$ by value; in empirical analysis, we isolate Norway's fund to ensure the results attributed to democratic funds are not driven by its investment).

\section{Measuring Sovereign Wealth Fund Political Independence}

We classify funds according to the degree of political independence enjoyed by their managerial teams. For this purpose, we use a variety of sources (media reports, fund disclosures, and fund websites) to identify directors and collect biographical data. We then classify directors as "politically connected directors" if they have held, in the past, any government role, elected or appointed, and as "private-sector directors" if otherwise. Finally, we compute the proportion of private-sector directors as a ratio of the number of private-sector directors over the total number of directors. We thus construct a variable measuring the proportion of private-sector directors ( $S W F$ independence) with values ranging from 0 (no private-sector directors) to 1 (all directors are from the private-sector). We use the most recent available data at the time of writing. Unfortunately, historical data is often unavailable, so a time-varying classification is not feasible. Our underlying assumption is that the degree of independence does not change significantly over time. We are somehow reassured by Truman (2011), as he notes slow evolution in SWF internal governance.

We document great variation in the proportion of independent directors. Norway's GPFG and Australia's Future Fund have the highest proportions of independent directors (at 86\%). Six funds have no private-sector directors (those based in China and Qatar, Oman's State General Investment Fund, the two funds from Abu Dhabi, and Dubai's Investment Corporation). ${ }^{10}$ 
In robustness tests, we also employ a different measure of fund independence, based on scores by Truman (2008 and 2011) and Bagnall and Truman (2011). We discuss the construction of this variable in more detail when addressing robustness tests in Section 4.

\section{The Benchmark Sample}

We construct a "benchmark sample" to draw a comparison between SWF investments and similar investments by other, non-government-owned financial firms. We obtain this sample by downloading, from the Thomson Reuters SDC Platinum Mergers \& Acquisitions Database (SDC), data on all investments with announcement dates between December 1, 1980 and November 1, 2012, with a publicly traded target and with financial acquirers (acquirers having a Standard Industry Classification code between 6000 and 6999). We only keep transactions in which the acquirer originates from one of the 15 countries in which SWF acquirers in our sample are based; similarly, we only keep transactions for which the target firm is headquartered in one of the 54 countries in which SWF investment targets are headquartered. We further exclude transactions classified as leveraged buyouts, recapitalizations, selftender offers, exchange offers, repurchases, and privatizations. We also exclude all instances of debt restructurings (transactions with an acquisition technique labeled as "debt restructuring" or with an acquirer labeled as "creditor"). ${ }^{11}$ Transactions with the status listed as "rumor," "discontinued rumor," "status unknown," "seeking buyer," or "seeking buyer withdrawn" are also excluded. We further exclude all deals with SWF involvement, either marked as "SWF Involvement Buyside" or "SWF Involvement Sellside," or manually identified as having as a buyer or seller a SWF, a SWF subsidiary, or a SWF investment vehicle. We further exclude all deals in which the immediate or ultimate parent of either the target or the buyer is identified as "government," all transactions for which the target does not have a Datastream code, and all transactions with individuals as acquirers.

The resulting sample contains 5,350 observations with a total deal value of $\$ 474$ billion (adjusted to the year 2000).

\section{Other Variables}

Target-specific variables (Total assets, Return on assets, Quick ratio, Closely held shares, Sales growth, Debt to assets, and Market to book, as defined in Table A1 in the appendix) are from the Thomson Reuters Worldscope (Worldscope) database, in U.S. dollars. In the descriptive statistics and matching procedures, we present and employ target metrics as of December 31 of the year prior to the investment. Dollar-denominated metrics are scaled to 2000 U.S. dollars using the Consumer Price Index (All Urban Consumers) from the U.S. Bureau of Labor Statistics.

Daily stock price performance data and local equity index values are obtained from the Thomson Reuters Datastream (Datastream) database. We employ the Total return index, in U.S. dollars, to compute daily returns for individual equities and for associated market indices. We collect country-specific data for both acquirer and target nations: GDP per capita (defined as the target-country GDP in 2000 USD divided by national population), GDP growth, and Market capitalization to GDP (defined as the total market capitalization of all publicly listed domestic firms divided by GDP) are from the World Bank. Data on legal origin (as defined by La Porta et al., 1998) is from a dataset made available by Andrei Shleifer. ${ }^{12}$ Banking crises are identified using the dataset by Laeven and Valencia $(2010,2012)$.

\section{EMPIRICAL ANALYSIS}

\section{Event Studies}

We examine the valuation impact of SWF investments on target firms, both absolute and relative to comparable private-sector investments, by analyzing the market reaction at investment announcement using event-study methods. ${ }^{13}$ We present event-study results in this section.

Similar to Bortolotti, Fotak, and Megginson (2015), our main proxy for the impact of SWF investments on firm value is the abnormal stock price return at the time of the investment announcement. Cumulative abnormal returns (CARs) are computed by subtracting the market-model expected return 
from the target firm's stock total return over an interval around the day on which the announcement of the investment occurs (day 0). ${ }^{14}$ We compute market-model expected returns by first estimating model parameters using daily returns over the year (250 trading days) ending 20 trading days prior to the announcement date. We employ three-day $(-1,+1)$ event window to capture the effect of possible previous-day leakage of information or next-day reaction (common when announcements occur "after hours" or in distant time zones), while avoiding the increased noise of the longer event window.

\section{The Sovereign Wealth Fund Discount}

Event-study results presented by BFM suggest that the value impact of SWF investors, while positive, is smaller than that of private sector investors. Yet BFM also reveal that SWF acquisitions differ significantly from those by private financial investors: SWFs tend to target larger and more profitable firms than do private-sector investors, but they also tend to acquire smaller stakes and assume control less frequently. These differences could affect the market reaction, creating potential problems in attributing causation. To test the valuation impact of SWFs, while accounting for possible differences in sample composition, we apply a methodology similar to Bortolotti, Fotak, and Megginson (2015), but with a focus on the SWF discount, rather than on decomposing the abnormal return into target and deal characteristics. We first identify a matched sample of private-sector investments sharing similar target and deal characteristics. We then compute the difference in market reaction between SWF investments and the matched sample. We call this difference a "SWF discount." Our proxy for the value impact of investments is the three-day cumulative abnormal return surrounding an investment announcement.

We identify matched investments by relying on propensity score matching: we first determine how SWF investments differ from private-sector investments on the basis of observable target and deal characteristics and then pick, for a reduced benchmark sample, private sector investments that most resemble investments by SWFs. ${ }^{15}$ Accordingly, to model the SWF target selection process, we estimate coefficients of a probit model. The response is a binary variable equal to one when the investor is a SWF and to zero when the investor is a non-government-owned financial entity. The set of predictors includes firm, country, and deal characteristics. In selecting the exact metrics to use, we replicate, as much as data availability constraints allow, the approach by Kotter and Lel (2011) and Bortolotti, Fotak, and Megginson (2015). We include variables measuring deal characteristic in the probit model (Stake, Control, Capital injection, First investment, and Control) and industry and year fixed effects. Standard errors are clustered at the investment-target level. To mitigate the impact of outliers, all continuous variables are winsorized at the 1st and 99th percentiles of the distribution. Estimation results are included in Appendix Table A3.

Based on estimated coefficients, we compute a probability score, reflecting the likelihood of the acquirer being a SWF. Finally, we select, with replacement, the private sector investment matched to each SWF investment with the closest probability score. ${ }^{16}$ To estimate the discount component attributable to the SWF identity, we compute the mean difference between abnormal returns on the SWF investment sample and this matched sample. As reported in Table 1, the average three-day cumulative abnormal return at the announcement of a SWF investment is $0.50 \%$, while, for the matched private-sector sample, it is $1.81 \%$. The estimated target discount is equal to $-1.31 \%$, which is both economically and statistically significant (at $1 \%$ ).

Our main interest lies in the distinction between democratic and autarchic funds, and in how those funds can mitigate this discount. Accordingly, we partition the sample based on whether SWFs are based in a democratic country (Norway, Australia, South Korea, or Malaysia), or otherwise. We then replicate the analysis described above for the two data subsets. We find a statistically significant SWF discount in both subsamples. In line with the political interference hypothesis, the discount appears almost $40 \%$ larger for autarchic funds $(-1.57 \%)$ than for democratic ones $(-1.12 \%)$. 
TABLE 1

DECOMPOSITION OF ANNOUNCEMENT PERIOD ABNORMAL RETURNS

\begin{tabular}{|l|c|c|c|}
\cline { 2 - 4 } \multicolumn{1}{c|}{} & $\mathbf{N}$ & Mean CAR (-1, +1) & \multicolumn{1}{c|}{} \\
\hline SWF & 558 & $0.50 \%$ & 0.59 \\
\hline Matched & 558 & $1.81 \%$ & $-3.77^{* * *}$ \\
\hline SWF Discount & 558 & $-1.31 \%$ & $-4.98^{* * *}$ \\
\hline \multicolumn{2}{|l}{} \\
\hline $\begin{array}{l}\text { SWF Discount (SWFs from democratic } \\
\text { countries) }\end{array}$ & 320 & $-1.12 \%$ & $-2.14^{*}$ \\
\hline $\begin{array}{l}\text { SWF Discount (SWFs from autarchic } \\
\text { countries) }\end{array}$ & 234 & $-1.57 \%$ & \\
\hline
\end{tabular}

This table includes mean cumulative abnormal stock returns (CARs), in U.S. dollars, for target firms' common equity on the days surrounding the announcement of an investment. Daily abnormal returns are computed using a market model with parameters estimated over 250 trading days ending 20 trading days prior to the investment announcement. Returns are cumulated over the three-day trading period surrounding the announcement of the investment (day 0). Cumulative abnormal returns are computed for the sample of SWF investments for which matched observations and returns data are available. The matched sample is matched on target and deal characteristics, based on the model presented in Table A1 in the Appendix. Cumulative abnormal returns are winsorized at the 1st and 99th percentiles; means are tested using $t$-statistics computed with standard errors clustered at the SWF level. *, **, and *** indicate significance at the $0.10,0.05$, and 0.01 level.

\section{Mitigating the Discount, Regression Analysis}

We turn our attention to whether SWFs can mitigate the discount in market reaction by signaling a passive stance. We investigate the determinants of the discount by estimating the following investmentlevel OLS regression:

$Y_{i, l, j, t}=\alpha_{1}+\alpha_{2} X_{i, l, j, t}+\eta_{t}+\delta_{j}+\varepsilon_{i}$

The dependent variable $Y_{i, l, j, t}$ is the discount for investment $i$, by the SWF $l$, in country $j$, during year $t$, computed as the difference between the three-day CAR at SWF investment announcement and the threeday CAR at announcement of the propensity-score matched investment, as described in Section 4.2. The first model we estimate aims at identifying the effectiveness of "passivity signals" for all funds - we accordingly add the vector $X_{i, l, j, t}$ is the set of explanatory variables identifying whether the SWF has taken seats on the board of the target (Director), assumed a controlling stake (Control), measuring the size of the stake acquired (Stake), identifying cross-border deals (Foreign), direct investments (Direct investment), deals without partners (Unique acquirer), and deals with targets in regulated industries (Regulated industry). The terms $\delta_{j}$ and $\eta_{t}$ represent country and year fixed effects, respectively. $\varepsilon_{i}$ is the error term - in estimation, standard errors are clustered at the SWF level.

Estimation results are presented in the first column of Table 2. The coefficient associated with the intercept is negative and statistically significant (at the $10 \%$ level), confirming the existence of a sizable discount. The coefficient associated with the binary variable identifying foreign deals is positive and statistically significant (at the 10\% level), indicating that the discount is smaller for cross-border investments, consistent with the political interference hypothesis. On the other side, we find that the discount is smaller also for "unique acquirer" deals, contrary to our expectations-and the other "passivity signals" do not seem to reduce the discount.

Overall, this analysis does not yield strong evidence of effectiveness of passivity signals in mitigating the discount. Yet, our previous analysis has indicated that the discount is larger for autarchic funds. We 
conjecture that passivity signals could have a stronger impact when acquisitions are by autarchic funds. We accordingly attempt to investigate whether these mechanisms are equally effective for democratic and autarchic SWFs. We add to the model binary variables identifying autarchic SWFs and we interact this variable with the set variables identifying the passivity signals listed above. In addition, Norway's GPFG is often cited as being different from other SWFs, both in terms of internal organization and investment style - and accounts for a large number of democratic SWF deals. ${ }^{17}$ Consistently, we add a binary variable identifying investments by Norway's fund, an index of SWF independence (as previously discussed, the proportion of private-sector directors on the fund's board), and interaction terms between the index of SWF independence and the variable identifying autarchic SWFs. Our findings, presented in the second column of Table 2, paint a nuanced picture. First, the intercept, while negative (indicating a $9 \%$ discount), is no longer statistically significant. For democratic funds, we find that the market reaction, relative to private-sector investors, is positively related to the size of the stake acquired, to the acquisition of a majority stake, to foreign deals, and direct investments. The economic magnitude of the results is significant: for example, a controlling stake by a democratic SWF increases the market reaction by 6\%; a direct investment by an additional 11\%. Conversely, the interaction with autarchic funds reveals that controlling stakes and direct investments are associated with large discounts: a direct investment by an autarchic fund will increase the discount by about $5 \%$ (the sum of the coefficient estimates on Direct and $S W F$ autarchic $\times$ Direct); a controlling stake by an autarchic fund will increase the discount by about $22 \%$. Overall, these results suggest that democratic SWFs are rewarded by an active approach (large, controlling stakes and direct acquisitions), especially abroad. This suggests that markets view democratic SWFs as potentially value-enhancing blockholders. Conversely, controlling and direct stakes, signals of active investments, lead to larger negative reactions (a larger "SWF discount") for autarchic funds, suggesting that the threat of political interference dominates. In all tests, the degree of political independence of the SWF does not appear to be related to the magnitude of the SWF discount, suggesting that the presence of private-sector directors is not a credible signal of political non-interference.

TABLE 2

REGRESSION ANALYSES OF THE SWF DISCOUNT

\begin{tabular}{|l|c|c|c|}
\hline Variable & Discount (-1,+1) & Discount (-1,+1) & Discount (-1,+1) \\
\hline Intercept & $-0.1311^{*}$ & -0.0930 & $-0.2674 * * *$ \\
\hline & -1.84 & -0.67 & -3.55 \\
\hline SWF autarchic & & -0.0101 & 0.1239 \\
\hline SWF Norway & & -0.17 & 1.40 \\
\hline & & 0.0064 & 0.0132 \\
\hline SWF independence & & 0.12 & 0.25 \\
\hline & & -0.1764 & \\
\hline SWF political index & & -1.25 & 0.0986 \\
\hline & & & 1.53 \\
\hline SWF autarchic $\times$ SWF independence & & 0.1034 & \\
\hline & & 0.75 & -0.0824 \\
\hline SWF autarchic $\times$ SWF political index & & & -1.35 \\
\hline & & & -0.0128 \\
\hline Director & -0.0315 & -0.0168 & -0.92 \\
\hline & -0.91 & -1.29 & $0.0702 * * *$ \\
\hline Control & -0.1621 & $0.0635 * * *$ & 3.71 \\
\hline & -1.13 & 3.75 & $0.0005 *$ \\
\hline Stake & 0.0030 & $0.0009 * *$ & 1.82 \\
\hline
\end{tabular}




\begin{tabular}{|c|c|c|c|}
\hline Variable & Discount $(-1,+1)$ & Discount $(-1,+1)$ & Discount $(-1,+1)$ \\
\hline \multirow[t]{2}{*}{ Foreign } & $0.0367 *$ & $0.1087 * * *$ & $0.1142 * * *$ \\
\hline & 1.95 & 4.61 & 5.34 \\
\hline \multirow{2}{*}{ Direct investment } & -0.0042 & $0.1129 * * *$ & $0.1079 * * *$ \\
\hline & -0.23 & 8.06 & 5.97 \\
\hline \multirow[t]{2}{*}{ Unique acquirer } & $0.0541 *$ & 0.0534 & $0.0678 * *$ \\
\hline & 2.04 & 1.69 & 2.20 \\
\hline \multirow[t]{2}{*}{ Regulated industry } & 0.0039 & 0.0002 & 0.0002 \\
\hline & 0.44 & 0.05 & 0.06 \\
\hline \multirow[t]{2}{*}{ SWF autarchic $\times$ Director } & & -0.0433 & -0.0492 \\
\hline & & -1.25 & -1.40 \\
\hline \multirow[t]{2}{*}{ SWF autarchic $\times$ Control } & & $-0.2832 *$ & $-0.288 *$ \\
\hline & & -1.93 & -1.98 \\
\hline \multirow[t]{2}{*}{ SWF autarchic $\times$ Stake } & & 0.0027 & 0.0030 \\
\hline & & 1.32 & 1.52 \\
\hline \multirow[t]{2}{*}{ SWF autarchic $\times$ Foreign } & & -0.0418 & $-0.0667 * *$ \\
\hline & & -1.44 & -2.31 \\
\hline \multirow[t]{2}{*}{ SWF autarchic $\times$ Direct investment } & & $-0.1632 * * *$ & $-0.1505 * * *$ \\
\hline & & -5.18 & -4.45 \\
\hline SWF autarchic $\times$ Unique acquirer & & n.a. & n.a. \\
\hline \multirow[t]{2}{*}{ SWF autarchic $\times$ Regulated industry } & & 0.0025 & 0.0052 \\
\hline & & 0.09 & 0.19 \\
\hline Obs & 513 & 513 & 513 \\
\hline Adjusted R-squared & $15.80 \%$ & $17.80 \%$ & $17.38 \%$ \\
\hline Year FE & $\mathrm{Y}$ & $\mathrm{Y}$ & $\mathrm{Y}$ \\
\hline Country FE & $\mathrm{Y}$ & $\mathrm{Y}$ & $\mathrm{Y}$ \\
\hline
\end{tabular}

This table includes coefficient estimates from OLS regressions. The response variable is the "SWF discount," or the difference between market-model cumulative abnormal return over the three-day window surrounding an investments announcement for the SWF investment and a propensity score matched private-sector investment. All predictors are described in Table A1. Target country and year fixed effects are included. Standard errors are robust and clustered by SWF; $t$-statistics are reported below the coefficient estimates. ${ }^{*}, * *$, and $* * *$ indicate significance at the $0.10,0.05$, and 0.01 level.

\section{Robustness Test: Alternative Metric of Political Independence}

The results presented in Section 4.3 indicate that political independence does not affect the impact of SWFs on target valuation. Given the difficulty in measuring political independence, the lack of results might be due to noise in our dependent variable. Accordingly, we construct a different metric, previously employed in Bortolotti, Fotak, and Megginson (2015). We add the scores to Truman's (2008) question nine ("Is the role of the government in setting the investment strategy of the SWF clearly established"), question ten ("Is the role of the managers in executing the investment strategy clearly established?"), and question eleven ("Are decisions on specific investments made by the managers?"). We compute the final index as three minus the sum of the scores described above, so our political index ranges from zero to three, in quarter point increments, with higher values indicating higher degrees of political interference. We classify four funds not included in Truman (2008) as having the highest value on the political index. In unreported robustness tests, we re-estimate the model by omitting investments by those four funds and by assigning them the lowest value on the political independence index. In all cases, results are robust.

Not surprisingly, we find lower scores for political interference in SWFs originating from advanced OECD countries, such as Norway, Australia, and Korea. An effective shield against political interference is also in place at the Kuwait Investment Authority and the Singaporean funds. One limitation of our 
classification scheme is that the scores are time-invariant, as they are recorded at a single point in time, the year 2008. Accordingly, our analysis allows for cross-sectional comparison, but no time-series variation within each SWF's investment portfolio. We note, however, that extant studies (Truman 2011; Bagnall and Truman 2011) find little variation in Truman's scores across time, justifying that the use of a time-invariant metric. ${ }^{18}$

Results are reported in the third column of Table 2 . The negative and statistically significant intercept indicates the existence of a large discount, on average. The newly introduced variable measuring political interference ( $S W F$ political index) is not statistically significant. Once more, we find that, for democratic funds, the market reaction is positively related to "active" deal characteristics: large and controlling stakes and direct investments with no partners. The market reaction is stronger for foreign deals. But the market reaction is negatively related to direct investments and controlling stakes for autarchic funds - and the "foreign deal premium" is much smaller for autarchic than for democratic funds. Overall, this set of robustness tests largely confirms our previous findings.

\section{Robustness Test: Constraints on the Executive}

We have hypothesized that SWFs from democratic countries might be under a greater threat of political interference. Wang and Li (2016) argue that "SWF institutionalization is structurally rooted in a country's regime type and the number of veto players in public policymaking. Democracy promotes SWF institutionalization by its need for strong rule of law, voters trying to constrain opportunistic behaviors of politicians, and the free flow of information." In democratic regimes, lower constraints on the executive allow for greater political interference. The Polity IV database, from which we obtain the metrics of "democracy vs. autarchy" employed in the analysis so far presented, includes also a score for the level of "constraints on the ruling executive" - mirroring Wang and Li's "number of veto players." 19

In unreported robustness tests, we replace the "SWF democracy" variable with a binary variable identifying high levels of executive constraints (with "high" being above the median). Our core findings are unaffected. For funds from countries with low levels of executive constraints, small stakes and indirect investments mitigate the magnitude of the SWF discount. For funds from countries with high levels of executive constraints, large and controlling stakes, direct investments, and investments without partners are related to stronger market reactions.

We should note, however, the high level of correlation between measures of democracy and executive constraints. We are, ultimately, unable to properly distinguish between the impact of executive constraints and other features of democratic regimes (such as degree of political competition, transparency of the electoral process, strength of the legal system, freedom of the press, etc.).

Additionally, Wang and Li (2016) argue that the number of veto players has a non-linear impact on the quality of SWF governance: "When the number of veto players is very small, institutionalization is too rigid, constraining, and not preferred; when the number of veto players is moderate, it is optimal for veto players to manage their conflict over SWF governance in a more routine and institutionalized fashion; and when the number of veto players grows above a threshold, it becomes too costly to coordinate and produce mutually agreeable institutional rules." Accordingly, we explore non-linear effects by adding, in an additional model, the Polity value for "constraints on the ruling executive," the square of the latter variable, and their interactions with the usual signals of passivity. In untabulated results, we find no support for the hypothesized non-linear impact of executive constraints on market reactions.

\section{Operating Performance}

The evidence based on market reactions could be rational, and anticipate, in an efficient-market framework, the long-term impact of a SWF acquirer on firm valuation. On the other side, foreign acquirers, especially opaque state-affiliated funds originating from non-democratic regimes, could elicit irrational fears and trigger a protectionist or xenophobic reaction. Accordingly, we question whether the results we find in terms of market reaction are consistent with the long-term impact of SWFs on firm's 
profitability and valuation, or whether they reveal some irrational bias against SWFs or other government-owned acquirers.

We investigate the impact of SWFs on firm's profitability (proxied by its return on assets, or $R O A$ ) and valuation (market-to-book ratio). For each variable, we compute changes over the one, two, and three years following investment by the SWF. For example, in estimating the change in $R O A$ over the year following the SWF investment (say, for example, an investment that occurs during the year 2010), we compute the difference between $R O A$ as of the end of the calendar year following the investment (December 31, 2011) and the end of the year preceding the SWF investment (December 31, 2009). We proceed similarly over the two and three-year horizons and for all other variables. As in previous analyses, to mitigate the impact of outliers, all continuous variables are winsorized at the 1st and 99th percentiles of the distribution. We test the significance of these changes using $t$-tests with standard errors clustered at the target firm level. We also compute changes in operating performance variables for the benchmark sample. Finally, we compare the SWF and benchmark sample results by subtracting changes in the variable of interest for the benchmark sample from changes for the SWF sample. We present our findings in Table 3. The exact sample size used in each test is indicated in the table, but, in general, the number of available observations shrinks over the longer time horizons (for SWFs, sample sizes in this table range from 682 to 565). Survivorship biases raise questions about the interpretation of long-horizon analysis, yet, as long as survivorship biases affect our SWF and matched samples in a similar fashion, the analysis should lead to valid inference. In untabulated tests, we find no statistically significant difference between the rate of delisting of SWF investment targets vs. private-sector investment targets, over the one-, two-, and three-year windows following investments.

As reported in Table 3, we find that SWF targets experience a decline in profitability over all time horizons: Return on assets declines by 1.92 percentage points over one year, 0.96 over two, and 1.59 over three. In contrast, we observe an increase in $R O A$ in the matched sample, statistically significant over all horizons, equal to 1.85 percentage points at the three-year mark. The difference between sample means is statistically significant at all horizons and equal to approximately 3.44 percentage points at the three-year horizon. Kotter and Lel (2011) likewise observe a decline in Return on assets for SWF targets, yet they find a similar decline in in a sample of firms matched by country, industry, and profitability — which emphasizes how proper benchmarking (our benchmark sample includes not all firms, but firms that are targets of private-sector deals) affects the inference from these tests.

Similarly, we find the Market to book ratio showing a statistically significant decline over all time horizons. We observe no decline in Market to book for the benchmark sample. The difference-indifferences is negative and statistically significant over all horizons, indicating that valuation of SWF investment targets suffers over the three years following SWF investments.

We question whether there are differences in performance between targets of democratic and autarchic funds. Even more, we are interested in testing whether the passivity signals by autarchic funds - or the active-stance signals sent by democratic funds - are associated with stronger operating performance, as the short-term market reaction would suggest. We employ regression analysis. In results presented in column 1 of Table 4, the response variable is the difference in percentage change in $R O A$. We first compute the change in $R O A$ between the end of the year following SWF investment and the end of the year preceding the SWF investment, scaled by the ROA at the end of the year preceding SWF investment. We do the same for the matched private-sector investment. Finally, we compute the difference between the SWF and private-sector investment. The list of explanatory variables mirrors those included in Table 2. We find results highly consistent with the regression explaining the magnitude of the SWF discount. For democratic funds, large stakes and direct investments are associated with an increase in $R O A$. Cross-border deals are also associated with stronger $R O A$. On the other side, for autarchic funds, we find that the size of the stake and direct investments are associated with negative interactions. We note one puzzling findings: independent SWFs (those with a large portion of non-political directors) are associated with a decline in $R O A$, contrary to our expectations. Statistically significant is, however, weak.

We replicate similar analysis on the change in market-to-book ratio. We find that, for democratic funds, electing directors to the board leads to higher valuation ratios, while the opposite is true for 
autarchic funds. In addition, we find valuation to be negatively related to direct investments and to investments in regulated industries.

The findings in our analysis of operating performance reveal weaker statistical significance (perhaps due to a smaller sample, due to data availability issues) than the analysis of abnormal returns at announcement. Yet, overall, they paint a consistent picture. The weaker short-term market reaction we note is consistent with a relative deterioration in operating performance. Even more, an active stance (large stakes and direct investments) is associated with higher profitability when funds are democratic, but the opposite is true for autarchic funds. Similarly, an active approach (electing directors) is associated with higher valuations for democratic funds, but lower valuation for autarchic funds.

The results presented in this section deal with a short time horizon, up to year $t+1$, where year $t$ is the year during which the SWF (matched) investment takes place. In untabulated analysis, we obtain similar results over longer time horizons, but, while coefficient estimates are similar in magnitude, statistical significance is weaker, likely due to the sample size shrinking at longer horizons.

TABLE 3

ANALYSIS OF LONG-TERM PERFORMANCE CHANGES AFTER INVESTMENT

Panel A: Return on assets

\begin{tabular}{|c|c|c|c|c|c|}
\hline \multicolumn{1}{|c|}{$\begin{array}{c}\text { Return on assets } \\
\text { (change relative to the year } \\
\text { prior to the investment) }\end{array}$} & Year & Mean & Median & t-stat & Obs \\
\hline \multirow{2}{*}{ SWF } & & & & & \\
\hline & 1 & $-1.92 \%$ & $-0.90 \%$ & $-3.63^{* * *}$ & 682 \\
\cline { 2 - 5 } & 2 & $-0.96 \%$ & $-1.05 \%$ & $-1.84^{*}$ & 616 \\
\cline { 2 - 5 } & 3 & $-1.59 \%$ & $-1.09 \%$ & $-3.12^{* * *}$ & 565 \\
\hline \multirow{2}{*}{ Benchmark } & 1 & $2.04 \%$ & $0.01 \%$ & $3.21^{* * *}$ & 3044 \\
\cline { 2 - 5 } & 2 & $3.89 \%$ & $0.41 \%$ & $5.78^{* * *}$ & 2619 \\
\cline { 2 - 5 } & 3 & $1.85 \%$ & $0.01 \%$ & $2.46^{* *}$ & 2186 \\
\hline \multirow{2}{*}{$\begin{array}{c}\text { Difference } \\
\text { (SWF-Benchmark) }\end{array}$} & 2 & $-3.96 \%$ & $-0.91 \%$ & $-4.77^{* * *}$ & \\
\cline { 2 - 5 } & 3 & $-3.45 \%$ & $-1.46 \%$ & $-5.7 * * *$ & \\
\hline
\end{tabular}

Panel B: Market to book

\begin{tabular}{|c|c|c|c|c|c|}
\hline \multicolumn{1}{|c|}{ Market to book } & Year & Mean & Median & t-stat & Obs \\
\cline { 1 - 5 } $\begin{array}{c}\text { (change relative to the year } \\
\text { prior to the investment) }\end{array}$ & & & & & \\
\hline \multirow{2}{*}{ SWF } & 1 & -1.50 & -0.61 & $-8.19^{* * *}$ & 682 \\
\cline { 2 - 6 } & 2 & -1.30 & -0.46 & $-6.22^{* * *}$ & 616 \\
\cline { 2 - 6 } & 3 & -1.35 & -0.63 & $-5.31^{* * *}$ & 565 \\
\hline \multirow{2}{*}{ Benchmark } & 1 & 0.06 & -0.04 & 0.7 & 3080 \\
\cline { 2 - 6 } & 2 & 0.02 & -0.05 & 0.24 & 2660 \\
\cline { 2 - 6 } & 3 & 0.19 & -0.05 & -7.5 & 2217 \\
\cline { 2 - 6 } & 2 & -1.57 & -0.57 & $-7.64^{* * *}$ & \\
\hline \multirow{2}{*}{ Difference } & 3 & -1.53 & -0.58 & $-5.46^{* * *}$ & \\
\hline
\end{tabular}


This table presents mean changes (differences) in Return on assets and Market to book ratio (as defined in Table A1) for both the sample of SWF investments and for the benchmark sample. Variables are measured as of Dec. 31 of each year. The base value is as of Dec. 31 of the year preceding the investment. The difference reported for year 1 is the difference between the value as of Dec. 31 of the year following the investment and Dec. 31 of the year preceding the investment and values for years 2 and 3 are similarly computed. The related $t$-statistics refer to tests for means, with the null hypotheses being that the mean is equal to zero. "Difference" reports the difference the difference between the mean change for the SWF sample and the mean change for the benchmark sample. The statistical significance of mean differences is tested with two-sample $t$-tests. Obs. reports the number of observations. $*, * *$, and $* * *$ indicate significance at the $0.10,0.05$, and 0.01 level. Panel A reports results related to Return on assets. Panel B reports results related to Market-to-book ratios.

TABLE 4

OPERATING PERFORMANCE REGRESSIONS

\begin{tabular}{|c|c|c|}
\hline Variable & $\Delta$ ROA \% & $\triangle \mathrm{MTBV} \%$ \\
\hline \multirow[t]{2}{*}{ Intercept } & 6.9607 & 0.3121 \\
\hline & 0.78 & 0.28 \\
\hline \multirow[t]{2}{*}{ SWF autarchic } & 7.0385 & -1.5673 \\
\hline & 1.45 & -0.83 \\
\hline \multirow[t]{2}{*}{ SWF Norway } & 4.8325 & 1.9715 \\
\hline & 1.07 & 1.15 \\
\hline \multirow[t]{2}{*}{ SWF independence } & $-7.8621 *$ & 0.8543 \\
\hline & -1.94 & 1.60 \\
\hline SWF autarchic $\times S W F$ independence & na & na \\
\hline \multirow[t]{2}{*}{ Director } & 0.3532 & $1.0665 * * *$ \\
\hline & 0.44 & 3.62 \\
\hline \multirow[t]{2}{*}{ Control } & -4.6062 & -2.0722 \\
\hline & -1.30 & -1.38 \\
\hline \multirow[t]{2}{*}{ Stake } & $0.1916 * *$ & 0.0860 \\
\hline & 2.50 & 1.29 \\
\hline \multirow[t]{2}{*}{ Foreign } & $3.025 * *$ & -5.5881 \\
\hline & 2.17 & -1.72 \\
\hline \multirow[t]{2}{*}{ Direct investment } & $3.9077 *$ & $-2.3173 *$ \\
\hline & 1.82 & -1.81 \\
\hline \multirow[t]{2}{*}{ Unique acquirer } & -4.0344 & -0.1955 \\
\hline & -0.83 & -0.20 \\
\hline \multirow[t]{2}{*}{ Regulated industry } & 0.0387 & $-0.2036 * *$ \\
\hline & 0.08 & -3.01 \\
\hline \multirow[t]{2}{*}{ SWF autarchic $\times$ Director } & 0.0441 & $-1.7011 * *$ \\
\hline & 0.04 & -2.21 \\
\hline SWF autarchic $\times$ Control & na & na \\
\hline \multirow[t]{2}{*}{ SWF autarchic $\times$ Stake } & $-0.1564 *$ & -0.0625 \\
\hline & -1.92 & -0.86 \\
\hline \multirow[t]{2}{*}{ SWF autarchic $\times$ Foreign } & -5.6436 & 4.8806 \\
\hline & -1.46 & 1.52 \\
\hline \multirow[t]{2}{*}{ SWF autarchic $\times$ Direct investment } & $-4.9191 * *$ & 1.6581 \\
\hline & -2.62 & 1.12 \\
\hline SWF autarchic $\times$ Unique acquirer & na & na \\
\hline \multirow[t]{2}{*}{ SWF autarchic $\times$ Regulated industry } & 1.3621 & 0.7220 \\
\hline & 0.66 & 0.82 \\
\hline Obs & 365 & 362 \\
\hline
\end{tabular}




\begin{tabular}{|l|l|l|}
\hline Variable & $\Delta$ ROA \% & $\Delta$ MTBV \% \\
\hline Adjusted R-squared & $95.44 \%$ & $24.10 \%$ \\
\hline Year FE & Y & Y \\
\hline Country FE & Y & Y \\
\hline
\end{tabular}

This table includes coefficient estimates from OLS regressions. The response variables are differences (between a SWF investment target and propensity-score matched private-sector target) in percentage change in return on assets (in column 1) and market-to-book ratio (in column 2), between December 31 of year $(t+1)$ and December 31 of year $(t-1)$, where year $(t)$ is the year of investment. All variables are described in Table A1. Target country and year fixed effects are included. Standard errors are robust and clustered by SWF; $t$-statistics are reported below the coefficient estimates. $*, * *$, and $* * *$ indicate significance at the $0.10,0.05$, and 0.01 level.

\section{Do Sovereign Wealth Funds Signal a Passive Stance?}

Having shown that a passive stance is associate with higher valuation and stronger operating performance for autarchic countries, while the opposite is true for democratic SWFs, we question whether SWFs attempt to strategically signal an active or passive stance to influence the market reaction and their impact on target valuation. When we compare autarchic SWFs to democratic SWFs, we find that funds from autarchic countries are less likely to be insulated from government interference: the proportion of non-political directors is $83.07 \%$ for democratic funds, but only $38.32 \%$ for autarchic funds. Autarchic funds are more likely to elect representatives on the board of directors of the target $(7.61 \%$ of the deals, vs. $1.88 \%$ for democratic funds), more likely to acquire controlling stakes ( $7.61 \%$ vs. $0.97 \%)$, and more likely to acquire large stakes (the average stake is $15.32 \%$ for autarchic funds and $1.59 \%$ for democratic ones). They are also less likely to invest abroad (83.69\% of deals vs. $94.79 \%)$, more likely to invest directly rather than via subsidiaries $(61.10 \%$ vs. $5.65 \%)$, and more likely to invest in regulated industries (49.26\% vs. $46.82 \%)$. The only signal of a lower propensity for active investing comes from the statistics on deals with no partners: $96.19 \%$ of deals by autarchic funds are "unique acquirer" deals, while $99.76 \%$ of deals of democratic funds are. Yet, the difference does not appear economically meaningful.

Overall, these findings reveal that, despite the negative market reaction, funds from autarchic countries are more likely to take an active stance in their investments. Given the costs of such a stance (in terms of deteriorating investment value), our evidence strongly suggests that these funds value the ability to influence investment targets.

We further analyze the fund's voluntary statements in regard to activism and political interference, either included in annual reports, mission statements, websites, or conveyed by fund managers during media interviews. Nine of the nineteen funds we track commit verbally or in writing to an active approach (funds from Malaysia, China, Qatar, Australia, New Zealand, Korea, the Investment Corporation of Dubai and the two funds from Singapore). Interestingly, this list includes all of the funds we classify as "democratic." Only two funds commit to a passive approach and both are based in autarchic MiddleEastern regimes (Abu Dhabi and Kuwait). Two SWFs appear to be ambiguous, if not ambivalent, about their own stance. For example, in its 2016 annual report, Temasek's management first promises engagement ("As an engaged shareholder, we promote sound corporate governance in our portfolio companies"), just to contradict itself by committing to a passive stance a couple of sentences later ("Our portfolio companies are guided and managed by their respective boards and management; we do not direct their business decisions or operations"). ${ }^{20}$ Notably, the report continues by emphasizing the independence of the fund from political interference ("our investment, divestment and other business decisions are directed by our Board and management. Neither the President of Singapore nor our shareholder, the Singapore Government, is involved in our business decisions"). We find similar, conflicting statements by the Investment Corporation of Dubai.

Five of the funds include statements stressing the independence of managers from political interference (those based in Australia, Qatar, Kuwait, Norway, and Singapore's Temasek), although virtually all SWFs have, at some point or another, issued statements to the press stressing their independence and non-political nature. 
TABLE 5

SIGNALS OF PASSIVE INVESTMENTS, DEMOCRATIC VS. AUTARCHIC SWFS

\begin{tabular}{|c|c|c|c|c|c|c|}
\hline & \multicolumn{2}{|c|}{ SWF democratic } & \multicolumn{2}{|c|}{ SWF autarchic } & \multirow[b]{2}{*}{ Difference } & \multirow[b]{2}{*}{$t$-stat } \\
\hline & Mean & Obs & Mean & Obs & & \\
\hline SWF independence & $83.07 \%$ & 425 & $38.32 \%$ & 473 & $44.74 \%$ & $184.14 * * *$ \\
\hline Director & $1.88 \%$ & 425 & $7.61 \%$ & 473 & $-5.73 \%$ & $14.56^{* * *}$ \\
\hline Control & $0.97 \%$ & 414 & $7.61 \%$ & 368 & $-6.64 \%$ & $20.24 * * *$ \\
\hline Stake & $1.59 \%$ & 414 & $15.32 \%$ & 368 & $-13.72 \%$ & $-11.26^{* * *}$ \\
\hline Foreign & $94.79 \%$ & 422 & $83.69 \%$ & 472 & $11.10 \%$ & $26.76^{* * *}$ \\
\hline Direct investment & $5.65 \%$ & 425 & $61.10 \%$ & 473 & $-55.45 \%$ & $300.72 * * *$ \\
\hline Unique acquirer & $99.76 \%$ & 425 & $96.19 \%$ & 473 & $3.57 \%$ & $12.11 * * *$ \\
\hline Regulated industry & $46.82 \%$ & 425 & $49.26 \%$ & 473 & $-2.44 \%$ & 0.44 \\
\hline
\end{tabular}

This table includes descriptive statistics for the sample of SWF investments. For each variable, the table reports the mean and number of observations for the sub-sample of SWFs based in democratic countries and for the sub-sample of SWFs based in autarchic countries, the difference between means and the results of a two-sample $t$-test. Variables are defined in Table A1. ${ }^{*} * *$, and $* * *$ indicate significance at the $0.10,0.05$, and 0.01 level.

\section{CONCLUSIONS}

Extant research finds that the announcement-period abnormal returns of sovereign wealth fund (SWF) equity investments in publicly traded firms are positive, but lower than those of comparable private investments. We question whether this discount is specific to certain funds and whether it is larger for SWFs originating from less-democratic countries, as those funds are more likely to become vehicles of political pressures. Further, we investigate whether SWFs can mitigate such a discount by signaling a passive stance and thereby insulating investment targets from political interference.

We first document strong, robust evidence of a statistically and economically significant "SWF discount." We further find that this discount is larger for SWFs based in autarchic, rather than democratic, countries.

We further hypothesize that SWFs - and, in particular, autarchic SWFs - might be able to mitigate such discount by insulating the funds from political interference and by signaling a passive stance. Our evidence indicates that markets react favorably to signals of an active stance (large stakes and controlling stakes) by democratic SWFs. For autarchic SWFs we find, instead, a negative association with controlling stakes and direct investments, suggesting that markets value a passive stance by SWFs originating from autarchic countries.

We further inspect the impact of SWFs on the operating performance of target firms. In a regression framework, we confirm patterns mirroring the short-term market reaction: funds from autarchic countries are associated with stronger performance and greater valuation when they signal passivity, while the opposite is true for funds from democratic countries.

Finally, having shown that a passive stance is associate with higher valuation and stronger operating performance for autarchic countries, we test whether autarchic SWFs are more likely to signal passivity, but find that, despite the negative market reaction, funds from autarchic countries are more likely to take an active stance in their investments. Given the direct and evident costs of such a stance, our evidence suggests that these funds value the ability to influence investment targets.

Our research adds to the literature on SWFs. We show that the optimal strategy is for democratic funds to signal an active stance, while, for autarchic funds, to signal a passive approach. This distinction 
contributes to reconcile conflicting findings in extant literature and points to the fact that apparent inconsistencies are largely due to grouping very heterogeneous funds under the "SWF" label.

Yet, our findings have broader implications for foreign investors, both government-owned ones and private-sector ones. The adverse reaction we document is likely most severe for government-owned investors; yet, it would be interesting to investigate whether private-sector investors originating from autarchic countries suffer from similar adverse market reactions, and how those adverse reactions can be mitigated. Finally, we show that the political system of the SWF host country matters-but we fall short of identifying which elements of the political system truly matter. Robustness tests suggest that the number of veto players and constraints on the ruling executive are key determinants, but we cannot rule out other features of democratic regimes (free press, competitive elections, etc.) as being key drivers of the market reaction to SWF investments.

\section{ACKNOWLEDGEMENT}

We thank Laura Pellizzola and Nikola Trajkov for their research assistance. We thank Alessandro Scortecci, Markus Massi, Hashim Rashid, Massimiliano Castelli, participants to the 2018 Middle East Investment Summit in Dubai, the 2018 NYU-WGC Long-term Investment Conference in New York, the 2018 UBS Sovereign Investment Circle in Singapore, and the 2017 IFSWF annual meeting in Astana for comments and suggestions. We thank the Sovereign Investment Lab for its generous financial support. Our sponsors were not involved in the design of the study, nor in the collection, analysis, and interpretation of the data, nor in the writing of the report, nor in the decision to submit the article for publication.

\section{ENDNOTES}

1. Aggregate data for SWF assets under management and growth rates is from the Sovereign Wealth Fund Institute and Bocconi's Sovereign Investment Lab. Data for hedge funds is from the "2017 Preqin Global Hedge Fund Report"; data for private equity funds is from the "2017 Preqin Global Private Equity and Venture Capital Report."

2. Murtinu and Scalera (2016) tangentially touch upon mitigating mechanisms while analyzing the choice of internationalization strategy of SWFs. They find that opaque and politicized funds are more likely to invest via investment vehicles. While their analysis is limited to the use of investment vehicles, we investigate a broader range of potential signals of a passive stance. Further, the focus on their analysis is on the determinants of the use of investment vehicles, while we focus on their effectiveness as a tool to mitigate adverse market reactions.

3. There is, however, no consensus here. Some scholars have reached the opposite conclusion, that SWFs act as pure economic investors (for example, Avendano and Santiso, 2009; Balding, 2008; Loh, 2010; Epstein and Rose, 2009). Megginson and Fotak (2015) offer a more in-depth discussion about extant empirical research on the impact of SWFs.

4. We follow extant literature and define political regime type based on whether citizens are able to choose how and by whom they are governed. "Democracy" here implies free and fair elections of the executive and legislative offices, the right of common citizens to vote and compete for public office, and institutional guarantees for the freedom of association and expression such as an independent judiciary and the absence of censorship (Dahl 1971, 1998). On the other side, "autocracy" implies dictatorship or "limited pluralism" at best (Linz 2000).

5. We include Norway's Government Pension Fund Global since, despite its name, it is financed through oil revenues rather than through contributions by pensioners and does not have any explicit pension liabilities. Funds headquartered in the United Arab Emirates are defined as SWFs, as the emirates are the true decision-making administrative units.

6. We identify over 150 majority-owned (including fully owned) subsidiaries. In this manuscript, any reference to "SWF investments" includes investments by SWFs, by fully owned subsidiaries, and by majority-owned subsidiaries. 
7. Sources include the Lexis-Nexis database and the archives of Financial Times, New York Times, Wall Street Journal, GulfNews, the Associated Press, Reuters, and others.

8. Given its preference for small stakes acquired on open markets and thus often not widely reported, we rely on Form 13F-HR filings by Norges Bank Investment Management to track investments by Norway's GPFG. We take the filing date - the day when GPFG files a Form 13F-HR detailing its shareholdings in a listed firm - as the announcement date for event studies, since this is the date that the stock ownership information is first disclosed. Given our reliance on Form 13F-HR as a data source, this data is specific to investments in U.S. listed firms.

9. For comparison, Dewenter, Han, and Malatesta (2010) assemble a sample of 996 transactions spanning 1997 to 2008, but those include transactions not classified as new investments (such as transfers between SWF subsidiaries) and transactions that are disaggregated into multiple trades (for example, if a SWF acquires partial stakes in the same target through different subsidiaries, which we count as a single observation). The set of observations used in their empirical analysis is restricted to 227 investments and 45 divestments. Kotter and Lel (2011) study 503 SWF investments over the period 1980 to 2009, of which 417 are employed in empirical analysis. Knill, Lee, and Mauck (2012b) employ a sample of 231 SWF investments. Bortolotti, Fotak, and Megginson (2015) employ a similar sample of 1,018 investments. The major difference, accounting for a lower number of observations in our study, is due to the fact that we consolidate investments by SWF subsidiaries if contemporaneous, treating them as a single observation, and to the fact that we exclude from our sample the Dubai International Financial Center, as improved financial disclosure revealed that it is co-funded by private sources and thus not a SWF by our definition. In contrast, a handful of studies employ larger datasets on SWF shareholdings, rather than transactions. Fernandes (2014), Avendaño (2012), Avendaño and Santiso (2011), and Dyck and Morse (2011) examine samples of SWF shareholdings in as many as 26,000 companies, all for holdings as of year-end 2008 or earlier. Lacking information on the investment transaction, these studies are unable to gauge the valuation impact of SWF investments in an event-study framework.

10. We do not find data on directors for the funds based in Brunei and Libya and for Oman's Investment Fund. Anecdotal evidence indicates that these funds have no independent directors - or, at least, that they level of independence is low-hence, in our main analysis, we assume that the proportion of private-sector directors is zero. We verify that our results are robust to the exclusion of those funds from our sample. In addition, when the funds are managed by an external asset manager, as in the case of Norway's GPFG funds being invested by Norges Bank Investment Management (NBIM), we collect data on the proportion of independent directors on the board of the asset manager, as that is the more relevant decision-making unit.

11. These filters are standard in empirical studies using the SDC database. For example, the same filters are used in Ferreira, Massa, and Matos (2010), but there the authors further exclude all minority acquisitions, by Karolyi and Liao (2017), but there the authors further exclude all domestic deals, and by Bortolotti, Fotak, and Megginson (2015).

12. http://www.economics.harvard.edu/faculty/shleifer/dataset

13. The use of event studies to gauge the impact of a corporate event on firm value has long been standard in corporate finance literature. For a review of basic event study methodology, we refer interested readers to Lyon, Barber, and Tsai (1999).

14. Total returns for securities and local market indices are from Datastream and are adjusted for dividends and splits. Returns are computed in U.S. dollars, for both individual securities and local-market indices; unreported robustness tests verify that results are unaffected by this conversion.

15. Propensity score matching is not new in the empirical corporate finance literature. For example, Campello, Graham, and Harvey (2010) use the technique to investigate the impact of financial constraints on firms: for each "constrained" firm in their sample, they identify a non-constrained firm matched on size, ownership, ratings, and industry. Fernandes (2014) applies the methodology in a study of the long-term impact of SWF investments on the operating performance of investment targets (but, while we aim at identifying matched transactions, Fernardes identifies matched firms).

16. We verify that the matched transactions are indeed similar to SWF investments by testing for differences in average propensity scores and we find no statistically significant difference in propensity scores between the two samples. Roberts and Whited (2012) recommend propensity score matching with replacement.

17. Norway's GPFG is often described as being the most professionally managed and most transparent SWF. Various studies have focused on its structure and behavior (Caner and Grennes 2009; Ang, Goetzmann, and Schaefer 2009; Chambers, Dimson, and Ilmanen 2012), finding that its management, while reporting 
periodically to the government, is better insulated from political interference than any other SWF leadership team. In terms of investment style, GPFG makes exclusively foreign investments and has committed to acquiring small stakes - although the exact definition of "small" has varied over time. Our approach, isolating investments by GPFG, mirrors Dewenter, Han, and Malatesta (2010) and Bortolotti Fotak, and Megginson (2015).

18. Bagnall and Truman (2011) document a slight improvement in question nine (between the 2008 and 2011 datasets), but they warn of the improvement being possibly due to self-reporting bias.

19. The variable is described as follows: "Operationally, this variable refers to the extent of institutionalized constraints on the decision-making powers of chief executives, whether individuals or collectivities. Such limitations may be imposed by any 'accountability groups.' In Western democracies these are usually legislatures. Other kinds of accountability groups are the ruling party in a one-party state; councils of nobles or powerful advisors in monarchies; the military in coup-prone polities; and in many states a strong, independent judiciary. The concern is therefore with the checks and balances between the various parts of the decision-making process. A seven-category scale is used." From http://www.systemicpeace.org/inscr/p4manualv2015.pdf

20. http://www.temasek.com.sg/documents/download/downloads/20160706235822/TR2016_Singles.pdf

\section{REFERENCES}

Ang, A., Goetzmann W., \& Schaefer, S. (2009). Evaluation of active management of the Norwegian Government Pension Fund-Global. Report to the Norwegian Parliament.

Ayyagari, M., Demirgüç-Kunt, A., \& Maksimovic, V. (2006). How well do institutional theories explain firms' perceptions of property rights? Review of Financial Studies, 21, 1833-71.

Avendaño, R. (2012). SWF investments: Firm-level preferences to natural endowments. Working Paper. Paris School of Economics, Paris, France.

Avendaño, R., \& Santiso, J. (2011). Are sovereign wealth funds politically biased? A comparison with other institutional investors. In N. Boubakri \& J.-C. Cosset (Ed.), Institutional investors in global capital markets, 12, 313-53. Bingley, UK: Emerald Group Publishing Limited.

Bagnall, A. E., \& Truman, E. M. (2011). IFSWF report on compliance with the Santiago principles: Admirable but flawed transparency. Peterson Institute for International Economics Policy Brief.

Balding, C. (2008). A portfolio analysis of sovereign wealth funds. Working Paper. Peking University, Peking, China.

Bertoni, F., \& Lugo, S. (2014). The effect of sovereign wealth funds on the credit risk of their portfolio companies. Journal of Corporate Finance, 27, 21-35.

Bortolotti, B., Fotak, V., \& Megginson, W. (2015). The sovereign wealth fund discount: Evidence from public equity investments. The Review of Financial Studies, 28, 2993-3035.

Brav, A., Jiang, W., Partnoy, F., \& Thomas, R. S. (2008). Hedge fund activism, corporate governance, and firm performance. Journal of Finance, 63, 1729-1775.

Brown, S. J., \& Warner, J. B. (1985). Using daily stock returns: The case of event studies. Journal of Financial Economics, 8, 208-258.

Byrd, J. W., Hickman, K. A. (1992). Do outside directors monitor managers? Evidence from tender offer bids. Journal of Financial Economics, 32: 195-221.

Campello, M., Graham, J. R., \& Harvey, C. R. (2010). The real effects of financial constraints: Evidence from a financial crisis. Journal of Financial Economics, 97, 470-487.

Caner, M., \& Grennes, T. (2009). Sovereign wealth funds: The Norwegian experience. Working Paper, North Carolina State University, Raleigh, NC.

Caves, R. E., \& Mehra, S. K. (1986). Entry of foreign multinationals into the US manufacturing industries. In M. E. Porter (Ed.), Competition and global industries: 449- 481. Boston, MA: Harvard Business School Press.

Chambers, D., Dimson, E., \& Ilmanen, A. (2012). The Norway model. Journal of Portfolio Management, $38,67-81$. 
Chen, X., Harford, J., \& Li, K. (2007). Monitoring: Which institutions matter? Journal of Financial Economics, 86, 279-305.

Chhaochharia, V., \& Laeven, L. (2009). The Investment Allocation of Sovereign Wealth Funds. Working Paper. University of Miami, Miami, FL.

Cohen, B. J. (2009). Sovereign wealth funds and national security: The great tradeoff. International Affairs, 85, 713-731.

Cosset, J., \& Suret, J. (1995). Political risk and benefits of international portfolio diversification. Journal of International Business Studies, 26(2), 301-318.

Dahl, R. A. (1971). Polyarchy: Participation and opposition. New Haven: Yale University Press.

Dahl, R. A. (1998). On Democracy. New Haven: Yale University Press.

Dewenter, K. L., Han, X., \& Malatesta, P. H. (2010). Firm value and sovereign wealth fund investments. Journal of Financial Economics, 98, 256-278.

Donahoe, J. D. (1989). The privatization decision. New York: Basic Books.

Drezner, D. W. (2009). Sovereign wealth funds and the (in)security of global finance. Journal of International Affairs, 62 (1), 115-130.

Dyck, A. I.J., \& Morse, A. (2011). Sovereign wealth fund portfolios. Working paper. Chicago Booth School of Business.

Estrin, S., Hanousek, J., Kocenda, E., \& Svejnar, J. (2009). The effects of privatization and ownership in transition economies. Journal of Economic Literature, 47, 699-728.

Epstein, R., \& Rose, A. (2009). The regulation of sovereign wealth funds: The virtues of going slow. Working Paper, 469. John M. Olin Program in Law and Economics, Stanford, CA.

Fernandes, N. G. (2014). The impact of sovereign wealth funds on corporate value and performance. Journal of Applied Corporate Finance, 26, 76-84.

Ferreira, M. A., \& Matos, P. (2008). The color of investors' money: The role of institutional investors around the world. Journal of Financial Economics, 88, 499-533.

Ferreira, M. A., Massa, M., \& Matos, P. (2010). Shareholders at the gate? Institutional investors and the cross-border mergers and acquisitions. Review of Financial Studies, 23, 601-644.

Financial Times (1996). Survey - Czech Republic: Message from the people. December 6, 3.

García-Canal, E., \& Guillén, M. F. (2008). Risk and the strategy of foreign location choice in regulated industries. Strategic Management Journal, 29, 1097-1115.

Grogoryan, A. (2016). The ruling bargain: sovereign wealth funds in elite-dominated societies. Economics of Governance, 17, 165-184.

Harley, N. H. (1981). Radom risk models. In A. R. Knight \& B. Harrad (Eds), Indoor air and human health, Proceedings of the Seventh Life Sciences Symposium, 29-31 October 1981, Knoxville, USA: 69-78. Amsterdam: Elsevier.

Helleiner, E. (2009). The geopolitics of sovereign wealth funds: An introduction. Geopolitics, 14, 300 304.

Hutzschenreuter, T., \& Voll, J. C. (2007). Performance effects of "added cultural distance" in the path of international expansion: The case of German multinational enterprises. Journal of International Business Studies, advance online publication August 30. doi:10.1057/palgrave.jibs.8400312.

Kaminski, T. (2017).Sovereign Wealth Fund Investments in Europe as an Instrument of Chinese Energy Policy. Energy Policy, 101, 733-739.

Karolyi, G. A., \& Liao, R.C. (2017). State capitalism's global reach: Evidence from foreign acquisitions by state-owned companies. Journal of Corporate Finance, 42, 367-391.

Klein, A. M., \& Zur, E. (2009). Entrepreneurial shareholder activism: Hedge funds and other private investors. Journal of Finance, 64, 182-229.

Knill, A. M., Lee, B.S., \& Mauck, N. (2012a). Bilateral political relations and sovereign wealth fund investment. Journal of Corporate Finance, 18, 108-123.

Knill, A. M., Lee, B.S., \& Mauck, N. (2012b). Sovereign wealth fund investment and the return-to-risk relationship of target firms. Journal of Financial Intermediation, 21, 315-40. 
Kotter, J., \& Lel, U. (2011). Friends or foes? Target selection decisions of sovereign wealth funds and their consequences. Journal of Financial Economics, 101, 360-81.

La Porta, R., López-de-Silanes, F., Shleifer, A., \& Vishny, R.W. (1998). Law and finance. Journal of Political Economy, 106, 1113-50.

Laeven, L., \& Valencia, F. (2010). Resolution of banking crises: The good, the bad, and the ugly. Working Paper. International Monetary Fund, Washington, DC.

Laeven, L., \& Valencia, F. (2012). Systemic banking crises database: An update. Working Paper. International Monetary Fund, Washington, DC.

Linz, J. (2000). Totalitarian and Authoritarian Regimes. Boulder, CO: Lynne Rienner.

Loh, L. (2010). Sovereign wealth funds. States buying the world. UK \& Singapore: Global Professional Publishing.

Lyon, J., Barber, B.M., \& Tsai, C. L. (1999). Improved methods for tests of long-run abnormal stock returns. Journal of Finance, 54, 165-201.

Mattoo, A., \& Subramanian, A. (2008). Currency undervaluation and sovereign wealth funds: A new role for the world trade organization. Working Paper. Peterson Institute, Washington, DC.

Megginson, W. L., \& Fotak, V. (2015). Rise of the fiduciary state: A survey of sovereign wealth fund research. Journal of Economic Surveys, 299, 733-778.

Megginson, W. L., \& Netter, J. M. (2001). From state to market: A survey of empirical studies on privatization. Journal of Economic Literature, 39, 321-89.

Miracky, W. F., \& Bortolotti, B. (2009). Weathering the storm: Sovereign wealth funds in the global economic crisis of 2008. Monitor Group \& Fondazione Eni Enrico Mattei.

Murtinu, S., \& Scalera, V.G. (2016). Sovereign wealth funds' internationalization strategies: the use of investment vehicles. Journal of International Management, 22, 249-264.

Norris, W. J. 2016. Chinese economic statecraft. Commercial actors, grand strategy and state control. New York: Cornell University Press.

Roberts, M. R., \& Whited, T.M. (2012). Endogeneity in empirical corporate finance. Working Paper. Simon School, Rochester, NY.

Rodrik, D., \& Wacziarg, R. (2005). Do democratic transitions produce bad economic outcomes? American Economic Review, 95, 50-55.

Shleifer, A., \& Vishny, R. W. (1986). Large shareholders and corporate control. Journal of Political Economy, 94, 461-88.

Shleifer, A., \& Vishny, R. W. (1994). Politicians and firms. Quarterly Journal of Economics, 109, 9951025.

The Investment Company Institute (2004). Worldwide mutual fund assets and flows, third quarter 2003. Retrieved February 4, 2004, from http://www.ici.org

Truman, E. M. (2008). A Blueprint for sovereign wealth fund best practices. Peterson Institute for International Economics Policy Brief.

Truman, E. M. (2011). Are Asian sovereign wealth funds different? Asian Economic Policy Review, 6, 249-68.

Wang, D., \& Li, Q. (2015). Democracy, veto player, and institutionalization of sovereign wealth funds. International interactions, 42(3), 377-400. 


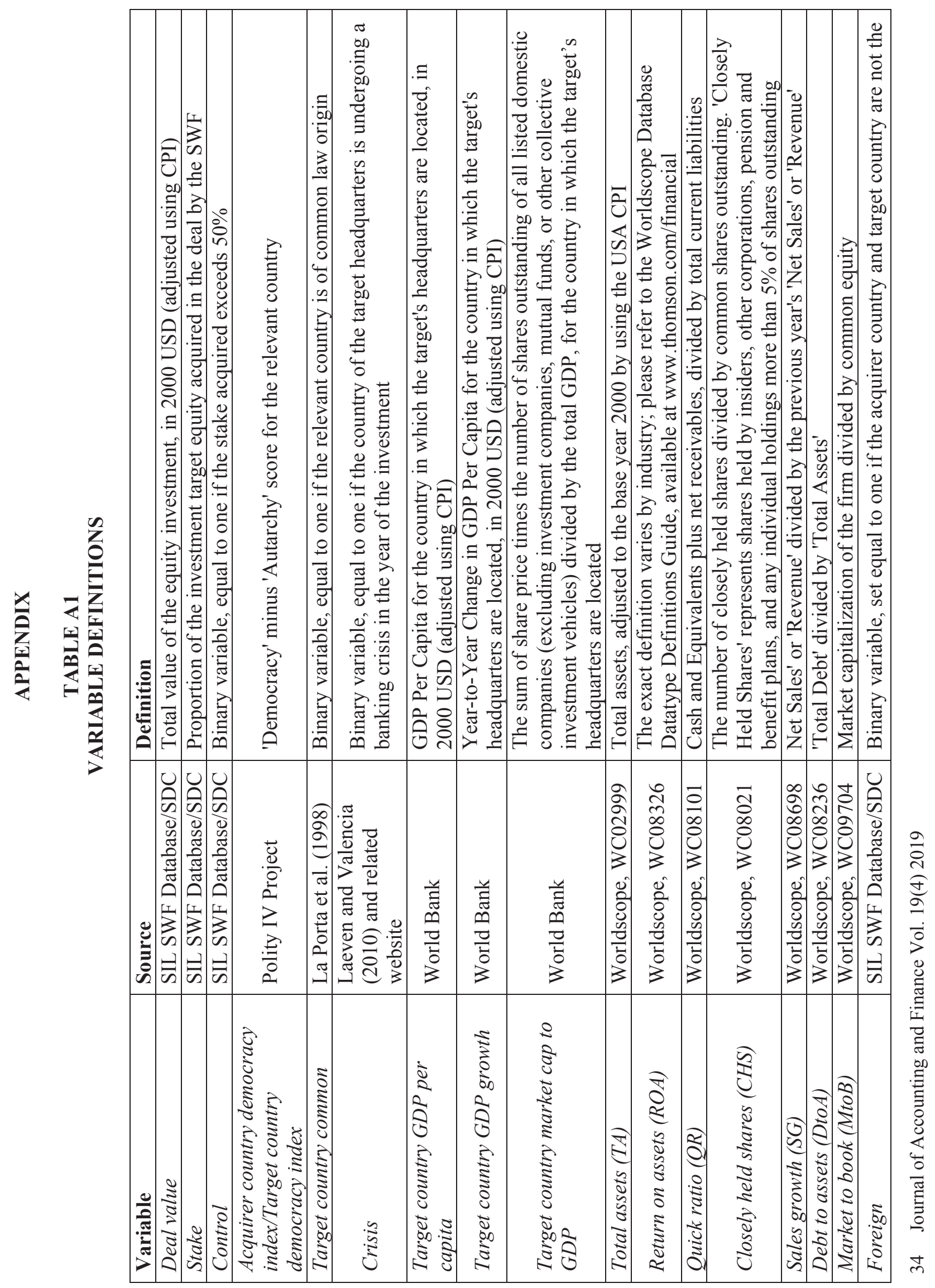




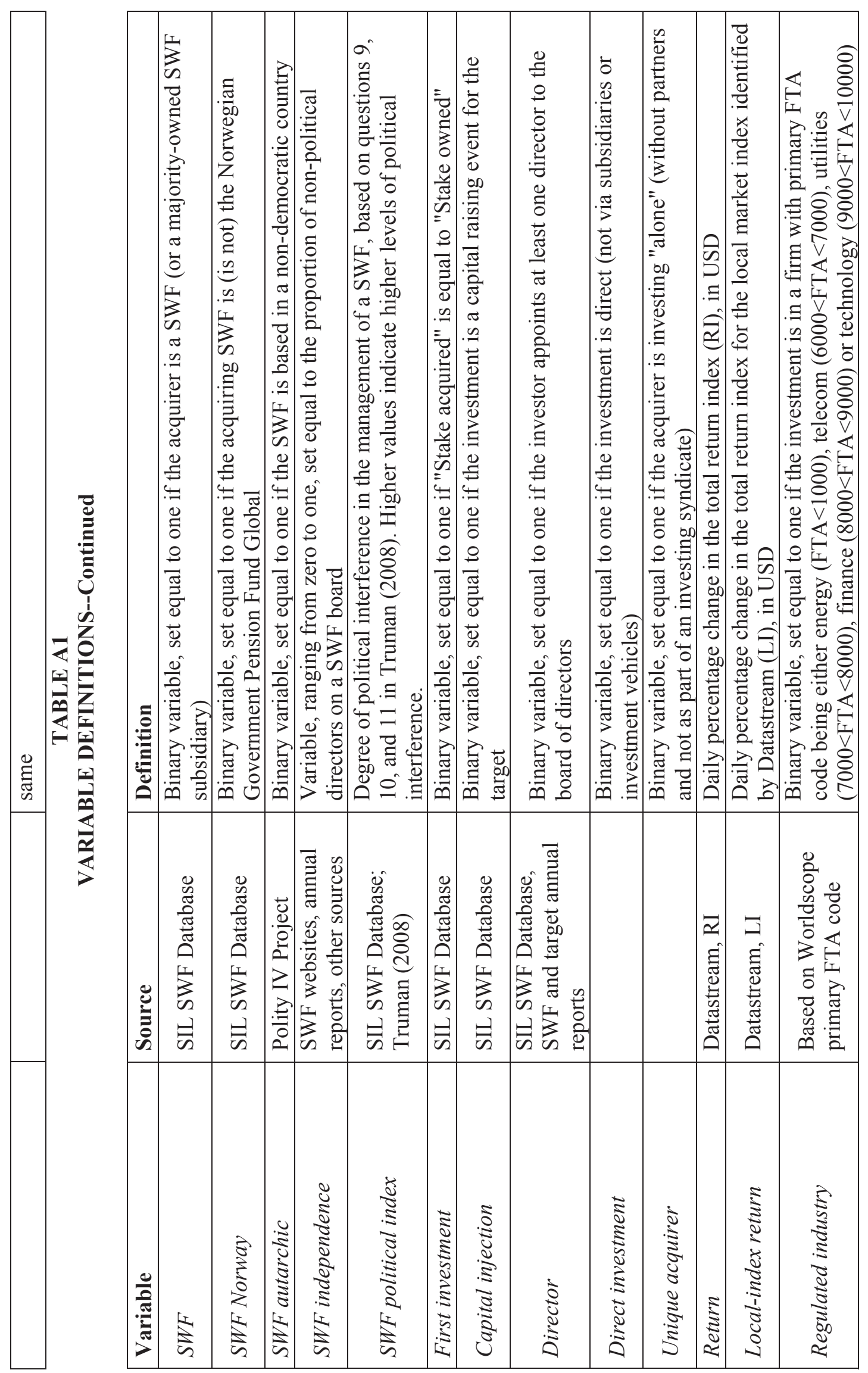




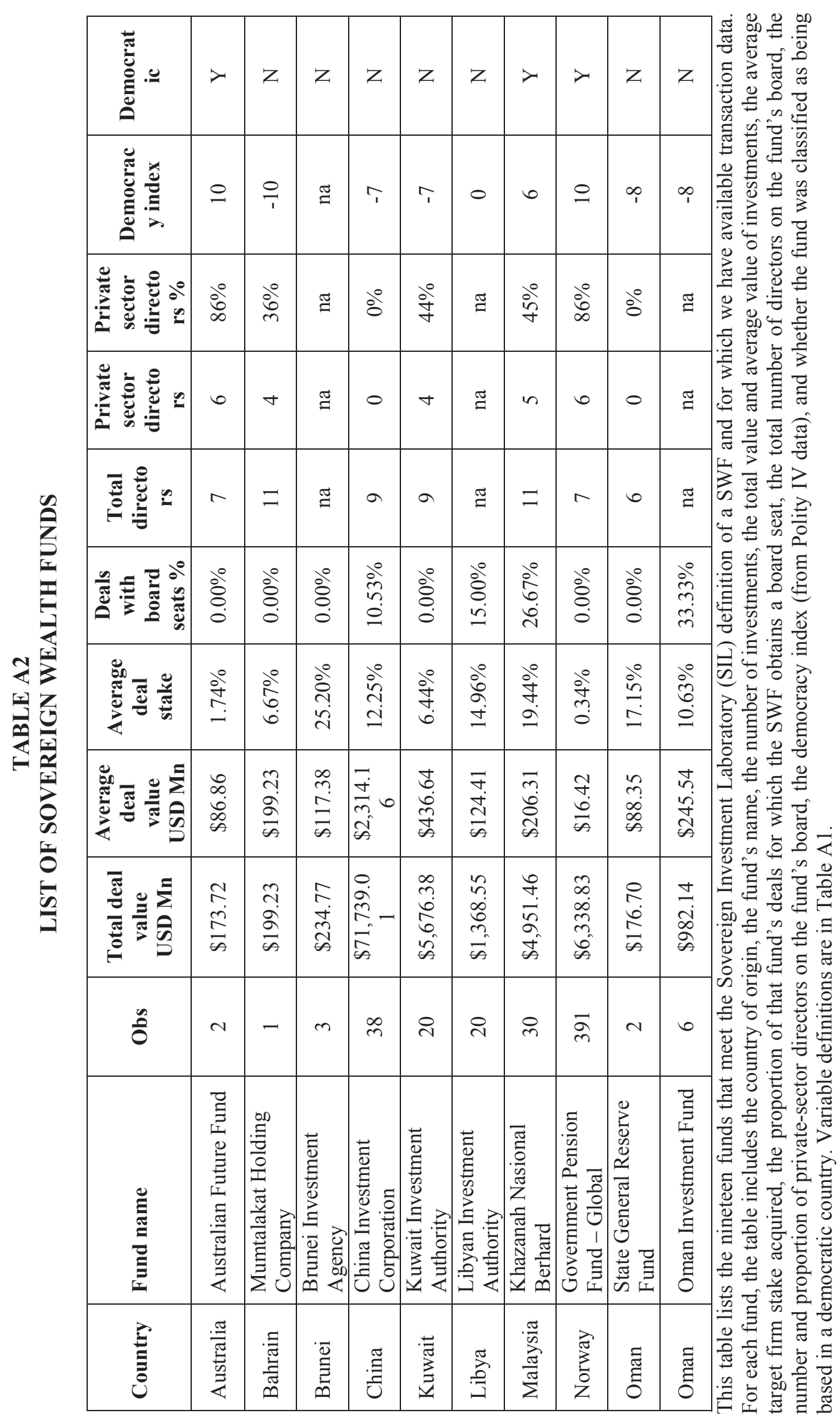

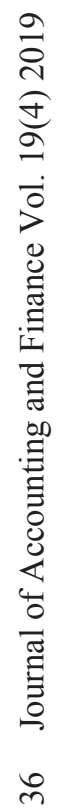




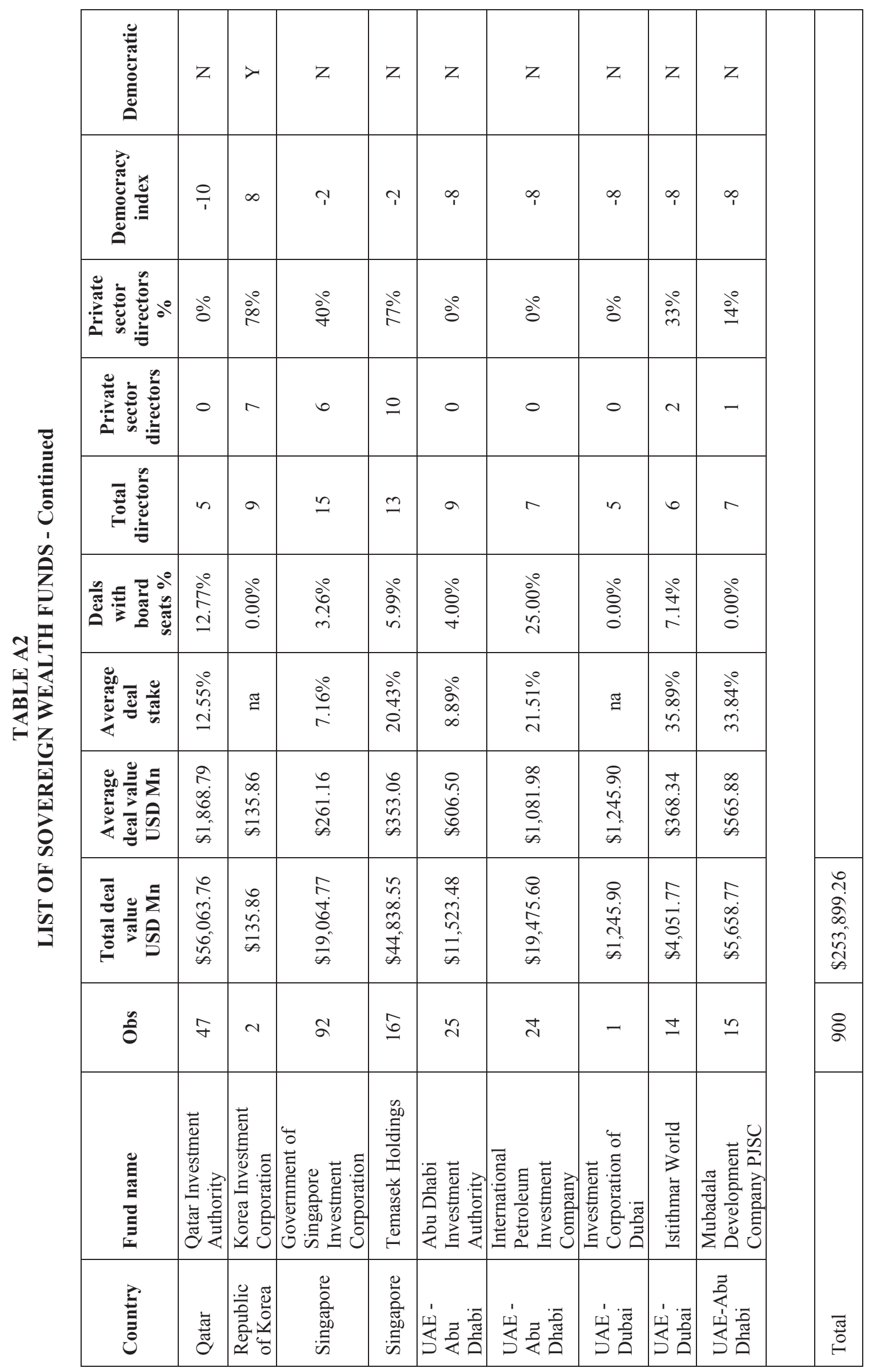




\section{TABLE A3 \\ PROBABILITY OF SWF AS AN ACQUIRER DETERMINED FROM A PROBIT MODEL}

\begin{tabular}{|c|c|}
\hline Variable & SWF Acquirer \\
\hline \multirow[t]{2}{*}{ Intercept } & $-7.8694 * * *$ \\
\hline & $(49.4011)$ \\
\hline \multirow[t]{2}{*}{ Foreign } & $-1.3965 * * *$ \\
\hline & $(83.1869)$ \\
\hline \multirow[t]{2}{*}{ Total assets $(\log )$} & $0.3856 * * *$ \\
\hline & $(99.1662)$ \\
\hline \multirow[t]{2}{*}{ Return on assets } & $0.0204 * * *$ \\
\hline & $(6.6507)$ \\
\hline \multirow[t]{2}{*}{ Debt to assets } & -0.0033 \\
\hline & $(0.6352)$ \\
\hline \multirow[t]{2}{*}{ Market to book } & 0.0139 \\
\hline & $(0.4464)$ \\
\hline \multirow[t]{2}{*}{ Closely held shares } & -0.0001 \\
\hline & $(0.0876)$ \\
\hline \multirow{2}{*}{$\begin{array}{l}\text { Buy and hold abnormal return, market } \\
\text { adjusted, previous year }\end{array}$} & $0.2126 * *$ \\
\hline & $(6.0246)$ \\
\hline \multirow[t]{2}{*}{ Target country GDP per capita (log) } & -0.0120 \\
\hline & $(0.0199)$ \\
\hline \multirow[t]{2}{*}{ Target country GDP growth } & 0.0388 \\
\hline & $(1.3782)$ \\
\hline \multirow[t]{2}{*}{ Market capitalization to GDP } & -0.0007 \\
\hline & $(0.1701)$ \\
\hline \multirow[t]{2}{*}{ Target country common } & $0.8504 * * *$ \\
\hline & $(15.405)$ \\
\hline \multirow[t]{2}{*}{ Democracy index, target country } & $-0.031 * *$ \\
\hline & $(4.0016)$ \\
\hline \multirow[t]{2}{*}{ Crisis } & $1.4628 * * *$ \\
\hline & $(57.2322)$ \\
\hline \multirow[t]{2}{*}{ Capital injection } & $0.4685 * *$ \\
\hline & $(4.7678)$ \\
\hline \multirow[t]{2}{*}{ Control } & $1.1155 * *$ \\
\hline & $(5.0576)$ \\
\hline \multirow[t]{2}{*}{ Stake } & $-0.0248 * * *$ \\
\hline & $(9.777)$ \\
\hline \multirow[t]{2}{*}{ First investment } & $0.5041 * * *$ \\
\hline & $(19.1403)$ \\
\hline Obs & 2,886 \\
\hline Percent concordant & $98.4 \%$ \\
\hline Percent discordant & $1.5 \%$ \\
\hline
\end{tabular}

This table includes coefficient estimates from a probit model. The response is a binary variable assuming the value of one if the investor is a SWF or a SWF-majority-owned subsidiary and zero otherwise. Variables are defined in Table A1. Industry and year fixed effects are included, but related coefficient estimates are omitted. Standard errors are clustered at the investment target level; Wald's chi-square test statistics are reported in parentheses below the related coefficient estimates. $* * *$, and $* * *$ indicate significance at the $0.10,0.05$, and 0.01 level. 